IOSR Journal of Pharmacy

e-ISSN: 2250-3013, p-ISSN: 2319-4219, www.iosrphr.org

Volume 2 Issue 6 ||| Nov-Dec. 2012 || | PP.05-11

\title{
A review on recent advances of enteric coating
}

\author{
Singh Deep Hussan*, Roychowdhury Santanu, Verma P., Bhandari V. \\ Sri Sai College of Pharmacy, badhani, pathankot, India
}

\begin{abstract}
Enteric coated tablets are solid unit dosage forms which are designed to bypass the stomach and release the drug in small intestine and are meant for oral administration. The word "enteric" indicates small intestine; therefore enteric coatings prevent release of medication before it reaches the small intestine. Most enteric coatings work by presenting a coated surface that is stable at the highly acidic pH found in the stomach, but breaks down rapidly at a less acidic (relatively more basic) $p H$. Materials used for enteric coatings include CAP, CAT, PVAP and HPMCP, fatty acids, waxes, shellac, plastics and plant fibers. The present review describes enteric coating, their ideal properties, benefits and limitation, various polymers used, their chemical structure, criteria for drug selection and mechanism, methods of manufacturing and evaluation of enteric coated tablets. Recently, these have attracted the interest of many formulators due to their advantages over the conventional drug delivery systems as they prolong the dosing intervals and also increase patient compliance. The study provides an overview of the recent advances that have taken place in this arena.

Keywords-Enteric coated tablet, Evaluation, Ideal Properties, Mechanism and Methods of enteric coated tablets.
\end{abstract}

\section{INTRODUCTION}

A tablet is a pharmaceutical dosage form comprising a mixture of active substances and excipients, usually in powder form, pressed or compacted from a powder into a solid dose. The excipients can include glidants (flow aids), diluents, binders or granulating agents and lubricants to ensure efficient tableting; disintegrants to promote tablet break-up in the digestive tract; sweeteners or flavours to enhance taste; and pigments to make the tablets visually attractive. A polymer coating is often applied to enhance the tablet's appearance or to make the tablet smoother and easier to swallow and to control the release rate of the active ingredient, to make it more resistant to the environment (extending its shelf life). "Caplets" are those tablets which are in the shape of capsules. Medicinal tablets and capsules are often called pills.

\subsection{Tablet coating}

Coating is a process by which an essentially dry, outer layer of coating material is applied to the surface of a dosage form in order to confer specific benefits that broadly ranges from facilitating product identification to modifying drug release from the dosage form. After making a good tablet, one must often coat it. $^{[1-3]}$

Coating may be applied to multiple range of oral solid dosage form, including tablets, capsules, multiparticulates and drug crystals. When coating composition is applied to a batch of tablets in a coating pan, the tablet surfaces become covered with a tacky polymeric film. Before the tablet surface dries, the applied coating changes from a sticky liquid to tacky semisolid and eventually to a non-sticky dry surface pans. The entire coating process is conducted in a series of mechanically operated acorn-shaped coating pans of galvanized iron stainless steel or copper. The smaller pans are used for experimental, developmental, and pilot plant operations, the larger pans for industrial production. ${ }^{[2-3]}$

1.1.1 Primary components involved in tablet coating

$>$ Tablet properties

$>$ Coating process

$>$ Coating equipments

$>$ Parameters of the coating process

$>$ Facility and ancillary equipments

$>$ Automation in coating processes. ${ }^{[2-3]}$

\subsubsection{Coating Process Design \& Control}

In most coating methods, when the tablets are being agitated in a pan, fluid bed, etc. at that time spraying on tablets by coating solution takes place. As the solution is being sprayed, a thin film is formed that adheres directly to each tablet. The coating may either be formed by a single application or may be built up in layers through the use of multiple spraying cycles ${ }^{[4]}$ In pharmaceutical industry, rotating coating pans are often 
used. Firstly, uncoated tablets are placed in the pan, which is typically tilted at an angle from the horizontal, and then the liquid coating solution is introduced into the pan while the tablets are tumbling. By passing air over the surface of the tumbling tablets, the liquid portion of the coating solution is then evaporated. In comparison, a fluid bed coater operates by passing air through a bed of tablets at a velocity sufficient to support and separate the tablets as individual units. Once separation takes place, then the tablets are sprayed with the coating composition. $^{[1-7]}$

The coating process is usually a batch operating task consisting of the following phases:

- Identification of batch and Recipe selection (film or sugar coating)

- Loading/Dispensing (accurate dosing of all required raw materials)

- Warming

- $\quad$ Spraying (Both application and rolling are carried out simultaneously)

- Drying

- Cooling

- Unloading

1.1.3 Coating equipment

A modern tablet coating system combines several components:

- A coating pan

- A spraying system

- An air handling unit

- A dust collector

\subsection{Advantages of tablet coating}

- Tablet coatings must not make tablets stick together during the coating process, must follow the fine contours of embossed characters or logos on tablets and must be stable and strong enough to survive the handling of the tablet.

- Printing on tablets can also be done by coatings, if required. Coatings are necessary for tablets giving a smoother finish, makes large tablets easier to swallow and also to mask the unpleasant taste.

\subsection{Disadvantages of tablet coating}

- Limitations of sugar coating such as relatively high cost, long coating time and high bulk have led to the use of other coating materials.

- However the process of coating is tedious and time-consuming and it requires the expertise of highly skilled technician.

\section{ENTERIC COATING}

An enteric coating is a barrier that controls the location of oral medication in the digestive system where it is absorbed. The word "enteric" indicates small intestine; therefore enteric coatings prevent release of medication before it reaches the small intestine. The enteric coated polymers remain unionise at low $\mathrm{pH}$, and therefore remain insoluble. But as the $\mathrm{pH}$ increases in the GIT, the acidic functional groups are capable of ionisation, and the polymer swells or becomes soluble in the intestinal fluid. Materials used for enteric coatings include CAP, CAT, PVAP and HPMCP, fatty acids, waxes, shellac, plastics and plant fibers.

There are four reasons for putting such a coating on a tablet or capsule ingredient:

$\checkmark$ Protection of active pharmaceutical ingredients, from the acidic environment of the stomach (e.g. enzymes and certain antibiotics).

$\checkmark \quad$ To prevent gastric distress or nausea from a drug due to irritation (e.g. sodium salicylate).

$\checkmark \quad$ For the delivery of drugs that are optimally absorbed in the small intestine to their primary absorption site in their most concentrated form.

$\checkmark \quad$ To provide a delayed-release component for repeat action.

$\checkmark$ Required for minimizing first pass metabolism of drugs. ${ }^{[8]}$

The choice of the polymer and the thickness of the coated layer are critical to control the $\mathrm{pH}$ solubility profile of the enteric coated dosage form.

The most common drugs which cause stomach ulcers like aspirin, diclofenac and naproxen are frequently available with enteric coatings. Omeprazole, which is a drug which stops the stomach from producing acid, is itself broken down in acid and therefore the drug generally has an enteric coating around it either as a granule in the capsules or as a granule in the dispersible form. Sulfasalazine is used either for the treatment of Crohn's disease which is inflammation of the intestines or for the treatment of arthritis. When used for Crohn's disease where it is needed in the intestines to work, it is given with an enteric coating whereas for arthritis it is very often given without an enteric coating so that it can be absorbed more quickly. 
ERY-TAB is an antibacterial product containing erythromycin base in an especially enteric-coated tablet to protect it from the inactivating effects of gastric acidity and to permit efficient absorption of the antibiotic in the small intestine. ERY-TAB (erythromycin delayed-release tablets) are available for oral administration in three dosage strengths, each white oval tablet containing $250 \mathrm{mg}$, $333 \mathrm{mg}$, or $500 \mathrm{mg}$ of erythromycin as the free base. Other commercially available tablets are enteric coated aspirin. E.g. Micropirin ${ }^{\circledR}$ 75mg EC tablets and enteric coated peppermint oil. E.g. Colpermin ${ }^{\circledR}$

2.1 Ideal properties of enteric coating material

- Resistance to gastric fluids

- Susceptible/permeable to intestinal fluid

- Compatibility with most coating solution components and the drug substrate

- Formation of continuous film

- Nontoxic, cheap and ease of application

- Ability to be readily printed ${ }^{[3-5]}$

2.1.1 Polymers used for enteric coating

Table no:-1 Different polymer used for enteric coating

\begin{tabular}{|c|c|}
\hline Polymers & Dissolution pH \\
\hline Shellac (esters of aleurtic acid) & 7.0 \\
\hline Cellulose acetate phthalate (CAP) & 6.2 \\
\hline Poly(methacrylic acid-co-methyl methacrylate) & $5.5-7.0$ \\
\hline Cellulose acetate trimellitate (CAT) & 5.0 \\
\hline Poly(vinyl acetate phthalate) (PVAP) & 5.0 \\
\hline $\begin{array}{l}\text { Hydroxypropyl methylcellulose phthalate } \\
\text { (HPMCP) }\end{array}$ & $4.5-5.5$ \\
\hline
\end{tabular}

2.1.2. New materials used for tablet coating

Zein

- $\quad$ Aqua-Zein®, which is an aqueous zein formulation containing no alcohol.

- Amylose starch and starch derivatives

- Dextrins

2.2 Criteria for selection of drugs for $\operatorname{CDDS}^{[9]}$

Table no:-2 Different criteria used for the selection of drugs in CDDS

\begin{tabular}{|c|c|c|c|}
\hline Criteria & Pharmacological class & Non-peptide drugs & Peptide drugs \\
\hline $\begin{array}{l}\text { Drugs used for local } \\
\text { effects in colon } \\
\text { against GIT diseases }\end{array}$ & $\begin{array}{l}\text { Anti-inflammatory } \\
\text { drugs }\end{array}$ & $\begin{array}{l}\text { Oxyprenolol, } \\
\text { Metoprolol, Nifedipine }\end{array}$ & $\begin{array}{l}\text { Amylin, Antisense } \\
\text { oligonucleotide }\end{array}$ \\
\hline $\begin{array}{l}\text { Drugs poorly } \\
\text { absorbed from upper } \\
\text { GIT }\end{array}$ & $\begin{array}{l}\text { Antihypertensive and } \\
\text { antianginal drugs }\end{array}$ & $\begin{array}{l}\text { Ibuprofen, Isosorbides, } \\
\text { Theophylline }\end{array}$ & $\begin{array}{l}\text { Cyclosporine, } \\
\text { Desmopressin }\end{array}$ \\
\hline $\begin{array}{l}\text { Drugs for colon } \\
\text { cancer }\end{array}$ & Antineoplastic drugs & Pseudoephedrine & Epoetin, Glucagon \\
\hline $\begin{array}{l}\text { Drugs that degrade } \\
\text { in stomach and small } \\
\text { intestine }\end{array}$ & Peptides and proteins & $\begin{array}{l}\text { Bromophenaramine, 5- } \\
\text { Flourouracil, } \\
\text { Doxorubicin }\end{array}$ & $\begin{array}{l}\text { Gonadoreline, Insulin, } \\
\text { Interferons }\end{array}$ \\
\hline $\begin{array}{l}\text { Drugs that undergo } \\
\text { extensive first pass } \\
\text { metabolism }\end{array}$ & $\begin{array}{l}\text { Nitroglycerin } \\
\text { corticosteroids }\end{array}$ & Bleomycin, Nicotine & $\begin{array}{l}\text { Protirelin, sermorelin, } \\
\text { Saloatonin }\end{array}$ \\
\hline Drugs for targeting & $\begin{array}{l}\text { Antiarthritic and } \\
\text { antiasthamatic drugs }\end{array}$ & $\begin{array}{l}\text { Prednisolone, } \\
\text { hydrocortisone, } \\
\text { Amino salicylic acid }\end{array}$ & $\begin{array}{l}\text { Somatropin, } \\
\text { Urotoilitin }\end{array}$ \\
\hline
\end{tabular}

\subsection{Limitations}

The reliability and delivery efficiency is doubtful due to presence of wide range of $\mathrm{pH}$ values and different enzymes present in the GI tract which is encountered by the drugs before reaching the target site. ${ }^{[10]}$ 


\section{OBJECTIVE}

The present study attempts to give an insight into the gastro-resistant drug delivery systems, and enteric coated tablets, in particular. Recently, these have attracted the interest of many formulators due to their advantages over the conventional drug delivery systems. The study provides an overview of the recent advances that have taken place in this arena. ${ }^{[11]}$

\section{MECHANISM OF ENTERIC COATED TIME-RELEASE PRESS COATED (ETP) TABLETS}

ETP tablets are composed of three layers, a drug containing core tablet (rapid release function), the press coated swellable hydrophobic polymer layer (Hydroxy propyl cellulose layer (HPC), time release function) and an enteric coating layer (acid resistance function). ${ }^{[12,13]}$ The tablet does not release the drug in the stomach due to the acid resistance of the outer enteric coating layer. The enteric coating layer rapidly dissolves after gastric emptying and the intestinal fluid begins to slowly erode the press coated polymer (HPC) layer. Rapid drug release occurs when the erosion front reaches the core tablet since the erosion process takes a long time as there is no drug release period (lag phase) after gastric emptying.

The duration of lag phase (drug release period) is controlled either by the weight or composition of the polymer (HPC) layer. (Fig. 1)

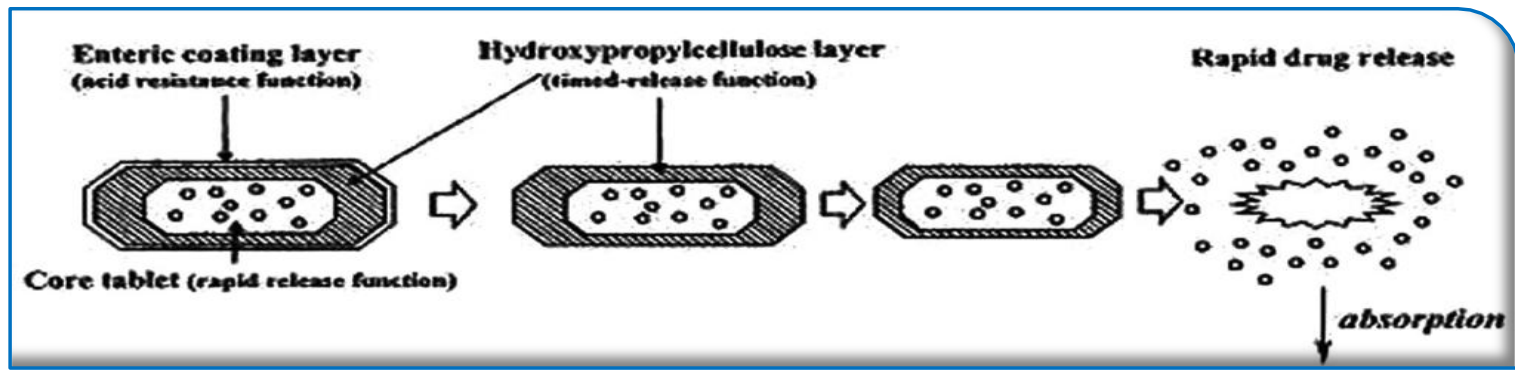

Figure 1: design of enteric coated timed-release press coated tablet (etp tablet)

\section{METHOD OF MANUFACTURING ENTERIC COATED TABLET BY SPRAY COATING TECHNIQUE ${ }^{[14]}$}

\subsection{Preparation of core tablets}

Granules were prepared using wet granulation method. Drug and other excipients were passed through \# 80 and add sufficient quantity of binding agent slowly to get dough mass. The mass was sieved through \# 8 and dried at $45^{\circ} \mathrm{C}$ for about $1 \mathrm{hrs}$. and then these granules were passed through \# 20 and lubricated with magnesium stearate. Mixed blend was compressed into tablets on single punch tablet compression machine to a weight of $250 \mathrm{mg}$ each with thickness of $4.46 \pm 0.21 \mathrm{~mm}$ and diameter of $7.9 \mathrm{~mm}$ using shallow concave plain/plain punch.

\subsubsection{Coating of core tablets: Preparation of enteric coating solution}

Weighed amount of pectin was dissolved in $50 \mathrm{ml}$ of water and ethyl cellulose was dissolved in $50 \mathrm{ml}$ of isopropyl alcohol. The two solutions were then mixed well to form a homogeneous solution and PEG-6000 was added as a plasticizer.

\subsubsection{Coating of core tablets}

Enteric coating of the compressed tablets is achieved by standard coating pan technique. Tablets were taken and were coated in a pan coater at $50 \mathrm{rpm}$ at a temperature of $50^{\circ} \mathrm{C}$ and at a flow rate of $10 \mathrm{ml} / \mathrm{min}$. Coating was carried out with spraying method and dried. These solutions are applied over tablets using spray gun at appropriate pressure. The coated tablets are primarily dried using heat blower and secondarily dried in tray drier.

\subsubsection{Coating methodology ${ }^{[15]}$}

Tablet coating was performed in a conventional coating pan with one spray gun. The coating pan was previously cleaned using alcohol $95 \%$. A batch size of $3.5 \mathrm{~kg}$ core tablets was selected for coating. The core tablets were loaded into the coating pan. Tablet cores were pre-heated to about $40^{\circ} \mathrm{C}$ utilizing a dryer and air compressor. Warm air was introduced into the coating pan (up to $50-55^{\circ} \mathrm{C}$ ) during the entire coating process.

The spray gun was filled with enteric coating solution and operated at a proper flow rate.

The pan was set into motion and seal coating dispersion was sprayed on to the falling cores under a suitable air pressure (87.0-116.0 psi) 6-8 bar. The air heater was switched off and tablets were blow dried for 20-25 minutes in the coating pan. The core tablets gained $10 \pm 2 \%$ weights after coating with enteric coating solution. 


\subsection{Additional considerations}

- There should always be a negative air pressure maintained in the pan (more air out than in).

- After start-up before making changes in fluid and/or air flows, always allow a minimum of 15 minutes for exhaust temperature to equilibrate.

- To achieve highest enteric quality and adhesion between the core and enteric interface, the spray rate of coating solution should be reduced by $15 \%$, for the first $1 \%$ weight gain, if any tackiness or sticking is noticed.

- $\quad$ Once coating solution delivery has begun, keep a constant flow rate.

- $\quad$ Keep gun needles in an open position during the coating process (Colorcon).

Tables 3 and 4 list the coating conditions and parameters Table no:-3 Parameters of coating process

\begin{tabular}{|ll|}
\hline Factor & Conditions \\
\hline Subuipment & Erweka Coating Pan \\
\hline Pan Charge & $50 \mathrm{mg}$ Erythromycin stearate tablets \\
\hline Dispersion solid content & $3.5 \mathrm{Kg}$ \\
\hline Pan speed & $15.0 \%(\mathrm{w} / \mathrm{w})$ \\
\hline Inlet Temperature & $14 \mathrm{rpm}$ \\
\hline Exhaust air temperature & $52-58^{\circ} \mathrm{C}$ \\
\hline Bed Temperature & $40-42^{\circ} \mathrm{C}$ \\
\hline Spray rate & $35-40^{\circ} \mathrm{C}$ \\
\hline $\begin{array}{l}\text { Distance between spray gun and tablet } \\
\text { bed }\end{array}$ & $50 \mathrm{~g} / \mathrm{min}$. \\
\hline Coating time & $15 \mathrm{~cm}$ \\
\hline
\end{tabular}

Table no:-4 Parameters of coating formulation

\begin{tabular}{|ll|}
\hline Parameter & Coating \\
\hline Theoretical weight gain $(\mathbf{m g})$ & $10 \pm 2 \%$ \\
\hline Polyethylene glycol (PEG 6000) & $1.4 \%(\mathrm{w} / \mathrm{w})$ \\
\hline Deionized water & $72.5 \%(\mathrm{w} / \mathrm{w})$ \\
\hline
\end{tabular}

\section{Evaluation of granules ${ }^{[16]}$}

\subsection{Measurement of the angle of repose}

The angle of repose was determined by the funnel method. The determination of angle of repose by this method is referred to as static angle of repose. Angle of repose is an indirect method of quantifying powder flow ability; because of their relationship with inter particle cohesion. A static heap will slide when the angle of inclination is large enough to overcome frictional forces and stop when gravitational forces balance the forces. The sides of heap will make an angle with horizontal which is called angle of repose. ${ }^{[17]}$ Powder is poured onto the centre of the dish from the funnel that can be raised vertically until the maximum cone height (h) is obtained. The angle of repose can be calculated by the given formulae.

$\alpha=\tan ^{-1}(\mathrm{~h} / \mathrm{r})$, where $\mathrm{h}$ is height of pile and $\mathrm{r}$ is radius of pile.

This was done thrice, from that average angle of repose and standard deviation was calculated.

\subsection{Pore/Bulk density}

The apparent true density $\left(\rho_{\mathrm{b}}\right)$ was measured by pouring the pre weighed $(\mathrm{M})$ blend into a graduated cylinder. The bulk volume $\left(\mathrm{V}_{\mathrm{b}}\right)$ of the blend was determined by this method. Then the true density was determined by the given below formulae.

$$
\rho b=M / V_{b}
$$

This was done thrice, from that average true density and standard deviation was calculated.

\subsection{Tap density}

The measured cylinder containing a known mass $(\mathrm{M})$ of blend was tapped for a fixed time, and the minimum volume $\left(\mathrm{V}_{\mathrm{t}}\right)$ occupied in the cylinder was measured. The tapped density was calculated by the formulae mentioned below.

Tap density $=\mathrm{M} / \mathrm{V}_{\mathrm{t}}$

This was done thrice, from that average tap density and standard deviation was calculated. 
6.4 Porosity ${ }^{[18]}$

The porosity of voids and of the powder is defined as the ratio of void volume to the bulk volume of the packaging.

$\mathrm{E}=(\mathrm{Vb}-\mathrm{Vp}) / \mathrm{Vb}=1-(\mathrm{Vp} / \mathrm{Vb})$

6.5 Carr's Index

Based on the apparent bulk density and the tapped density, the percentage compressibility of the bulk drug was determined by using the following formula.

$\%$ Compressibility = tapped density - bulk density/tapped density X100

6.6 Hausner's Ratio

The ratio of tapped density to bulk density of the powders is called the Hausner's ratio.

\section{EVALUATION OF CORE AND COATED TABLETS}

The core and coated tablets were evaluated for hardness, friability, weight variation, disintegration time, thickness, drug content and in vitro release studies.

\subsection{Hardness}

The tablet crushing strength was measured by using Monsanto tablet hardness tester. A tablet is placed between the anvils and the crushing strength, which causes the tablet to break, was recorded ${ }^{[19]}$.

\subsection{Friability}

Tablet strength was tested by Roche friabilator. Twenty tablets were accurately weighed and placed in the friabilator and operated for 100 revolutions in $4 \mathrm{~min}$. The tablets were dedusted and the percentage weight loss was calculated by reweighing the tablets. The tablets that loose less than $1 \%$ weight were considered to be compliant.

\subsection{Weight variation ${ }^{[14]}$}

In weight variation, twenty tablets were selected at random and average weight was determined using an electronic balance. Tablets were weighed individually and compared with average weight.

\subsection{Disintegration time ${ }^{[19]}$}

Disintegration time was determined using the disintegration apparatus USP in $0.1 \mathrm{~N} \mathrm{HCl}$ for 2 hrs. and then in phosphate buffer $\mathrm{pH} 6.8$ for 1 hour maintaining the temperature at $37 \pm 2{ }^{\circ} \mathrm{C}$.

\subsection{Thickness ${ }^{[14]}$}

The thickness of the tablet was measured by using vernier calipers.

\subsection{Drug content studies ${ }^{[14]}$}

Ten tablets were weighed individually and powdered; an amount equivalent to $5 \mathrm{mg}$ of drug was taken and $50 \mathrm{ml}$ of $95 \%$ ethanol was added and was shaken for 30 minutes. Sufficient ethanol (95\%) was added to produce $100 \mathrm{ml}$. It was centrifuged and suitable volume of the supernatant liquid equivalent to $0.5 \mathrm{mg}$ of drug was pipette out and diluted to $50 \mathrm{ml}$ with $95 \%$ ethanol. The solution was filtered (through $0.45 \mu \mathrm{m}$ ). Drug content was measured at $236 \mathrm{~nm}$ using UV/Visible single beam spectrophotometer.

\subsection{In vitro drug release studies ${ }^{[14]}$}

\subsubsection{In gastric and intestinal $\mathrm{pH}$}

In vitro drug release study of enteric coated tablets was carried out by using USP XXIV six station dissolution rate test apparatus with paddle stirrer. The dissolution rate was studied in $900 \mathrm{ml}$ of $0.1 \mathrm{~N} \mathrm{HCl}(\mathrm{pH}$ 1.2) maintained at a temperature of $37 \pm 1^{\circ} \mathrm{C}$ with a speed of $50 \mathrm{rpm}$ for first two hours followed by phosphate buffer (pH 7.4) for further four hours. Samples of $5 \mathrm{ml}$ were withdrawn after every hour, filtered (through 0.45 $\mu \mathrm{m})$ and replaced with $5 \mathrm{ml}$ of fresh dissolution medium. The samples were suitably diluted if necessary and estimated spectrophotometrically at $236 \mathrm{~nm}$ by using UV/Visible single beam spectrophotometer and cumulative percentage drug release was calculated.

\section{CONCLUSION}

From the above review, we can conclude that tablets are made enteric-coated for avoiding the first pass metabolism, gastric irritation and degradation and to direct the drug to the target intestines. Enteric coated tablets could be used to treat Streptococcal infections of the throat (strep throat) and the skin and can also be used in treating lung infections (pneumonias) caused by Streptococcal pneumoniae, Mycoplasma pneumoniae and Legionella pneumophila (Legionnaires disease). The choice of the polymer and the thickness of the coated layer are critical to control the $\mathrm{pH}$ solubility profile of the enteric coated dosage form. Drugs which are having low oral bioavailability ( $<50 \%$ ), short biological half life (about $3 \mathrm{hrs}$.) and an adequate protein binding that are preferred while formulating enteric coated dosage form. This dosage form is preferred as it is very convenient and easy to formulate, cost-effective and does not require high cost equipments. For that reason, this dosage form has been gaining so much attention nowadays. 


\section{REFERENCES}

[1]. Lachman L, Lieberman HA, Joseph LK. The Theory and Practice of Industrial Pharmacy. Varghese Publishing House; Mumbai; Third Edition: 297-321.

[2]. Lachman L, Liberman H, Kanig J. The Theory and Practice of Industrial Pharmacy; Third Edition: 293-345, 346373.

[3]. Aulton M. Pharmaceutics: The Science of Dosage Form Design. International Student Edition: 304-321, 347-668.

[4]. Vyas S, Khar R. Controlled Drug Delivery Concepts and Advances; First Edition: 219-256.

[5]. Ansel H, Allen L, Jr. Popovich N. Ansel's Pharmaceutical Dosage Forms and Drug Delivery Systems; Eighth Edition: 227-259.

[6]. Remington J. Remington: The Science and Practice of Pharmacy; 2(19): 1615-1641.

[7]. American Pharmaceutical Reviews 2001; 4(3): 28-35.

[8]. Kumar Vinay. KV, Sivakumar T and Tamizh mani. T, Colon targeting drug delivery system: A review on recent approaches, International Journal of Pharmaceutical and Biomedical Science, 2, 2011, 11-19.

[9]. Anil K. Philip and Betty Philip, Colon Targeted Drug Delivery Systems: A Review on Primary and Novel Approaches, Oman Medical Journal, 25(02), 2010, 70-78.

[10]. Aurora J, Talwar N and Pathak V. Colonic Drug Delivery Challenges and Opportunities - An Overview. European Gastroenterology Review 2006: 1-6.

[11]. Vachhani Savan R, Patel Jatin J, Patel Dipen, Prajapati ST and Patel CN, J. Chem. Pharm. Res., 2(2), 2010, 57-64.

[12]. Gazzaniga A, Iamartino P, Maffino G and Sangalli ME, Oral delayed release system for colonic specific drug delivery, Int J Pharm, 108, 1994, 77-83.

[13]. Hita V, Singh R, Jain SK. Colonic targeting of metronidazole using azo aromatic polymers, development and characterization. Drug Del 1997; 4: 19- 22.

[14]. D. Raju, J. Padmavathy, V. Sai Saraswathi, D. Saravanan and I. Aparna Lakshmi, Formulation and development of enteric coated tablets of prednisolone as a colon targeted drug delivery, IJPSR, 2(3), 2011, 685-690.

[15]. Abdel Naser Zaid and Aiman Qaddomi, Development and stability evaluation of enteric coated diclofenac sodium tablets using sureteric, Pak. J. Pharm. Sci., 25(01), 2012, 59-64.

[16]. Vidyadhara S, Chowdary YA, Murthy TEGK, Rao MV, Reddy KNK. Influence of electrolytes on controlled release of Ambroxol Hydrochloride from methocel matrix tablets. The Pharma Review 2006; June: 101-104.

[17]. Jaimini M, Rana AC, Tanwar YS. Formulation and Evaluation of Famotidine Floating Tablets. Current Drug Delivery 2007; 4: 51-55.

[18]. N. Damodharan, V. Manimaran and B. Sravanthi, Formulation development and evaluation of delayed release doxycycline tablets, International Journal of Pharmacy and Pharmaceutical Sciences, 2(1), 2010.

[19]. Patil Ajit, Payghan Santosh and Disouza John, Formulation and Evaluation of Enteric coated tablets of Azithromycin dihydrate, International Journal of ChemTech Research, 3(3), 2011, 1479-1484. 